\title{
CLIMATE CHANGE IMPACTS ON PLANT DISEASES
}

\author{
Tanmoy Das ${ }^{*}$,M. Hajong' D. Majumdar, R. K. Tombisana Devi and T. Rajesh
}

School of Crop Protection, Department of Plant Pathology, College off Post Graduate Studies, Central Agricultural University, Ribhoi-793103, Meghalaya, India

\begin{abstract}
The change in Global climate is due to increasing concentration of greenhouse gases (GHG) in the atmosphere. The earths' observed climatic changes over the past 50 years are primarily caused by various human activities. The increasing global temperature over the past century by about $0.8^{\circ} \mathrm{C}$ and expected to rise between 0.9 and $3.5^{\circ} \mathrm{C}$ by 2100 . Such changes will not only have a great effect on the growth and cultivation of different crops but also affect the reproduction, spread and severity of many plant pathogens. Various plant disease models have been developed to incorporate more sophisticated climate predictions at various levels. At the level, the adaptive potential of plant and pathogen populations may prove to be one of the most important predictors of the magnitude of climate change effects. This review highlights various influences of climate change on plant diseases and their effects with suitable examples.
\end{abstract}

Keywords: $\mathrm{CO}_{2}$, climate change, GHG, plant diseases, plant pathogens, temperature

\section{Introduction}

Climate change is a major environmental challenge worldwide. Green house gases $(\mathrm{GHG})$ viz., water vapour $\left(\mathrm{H}_{2} \mathrm{O}\right)$, carbon dioxide $\left(\mathrm{CO}_{2}\right)$, Methane $\left(\mathrm{CH}_{4}\right)$, nitrous oxide $\left(\mathrm{N}_{2} \mathrm{O}\right)$, hydrofluorocarbons (HFCs) and Ozone $\left(\mathrm{O}_{3}\right)$ in the atmosphere trap reflected radiation to warm the earth surface (Mahato, 2014). Human activities are widely involved in increasing global climate changes that directly influences the ecology (Pachauri and Reisinger, 2007 and Ahanger et al., 2013). In India, global warming was observed along the west coast, central India, the interior peninsula and Northeast India (Gautam, et al., 2013). According to Inter-govenrmental Panel on Climate Change (IPCC, 2007); the planet earth is experiencing a climate change and atmospheric $\mathrm{CO}_{2}$ is a major GHG, which increased by nearly $30 \%$ and temperature by $0.3-0.6^{\circ} \mathrm{C}$ (Chakraborty et al., 2000). This global climate changes by various factors (Pachauri and Reisinger, 2007 and Pachauri et al., 2014) and change or

\footnotetext{
*Corresponding author email: tanmoypath@gmail.com
} 
influence all the 3 major elements of disease triangle, viz., host, pathogen and environment (Legreve and Duveiller, 2010). Crop growth and production can be significantly affected due to high atmospheric $\mathrm{CO}_{2}$ concentration, temperature, changes in precipitation patterns and frequency of extreme weather phenomena and diseases presence will altered under these condition (Rosenzweig and Tubiello, 2007, Ghini et al., 2008 and Chakraborty, 2011). When the host present pathogens with short life cycles, reproduction rates is high and dispersion mechanisms respond quickly and adapt faster to climate change (Coakley et al., 1999).

Climate change would affect plant diseases together with anthropogenic processes such as air, water and soil pollution, long-distance introduction of exotic species and urbanization (Regniere, 2012). These factors contribute to the spread of diseases viz. sudden oak death (Prospero et al., 2009). Elevated temperature and $\mathrm{CO}_{2}$ concentration have impact on plant-disease interaction (Lopez et al., 2012) and posing a higher threat perception of late blight (Phytophthora infestans) of potato and blast (Magnaporthe grisea) and sheath blight (Rhizoctonia solani) of rice (Kobayashi et al., 2006). Effects of climate change on Phoma (Leptosphaeria maculans) in rape seed was observed through a model in combination with climate change that predict temperature and rainfall under $\mathrm{CO}_{2}$ emission scenarios for the 2020 and 2050s in UK (Evans et al. (2007); and sporulation of teleomorphs on climate change (Kaczmarek et al., 2016).

For sustainable food production disease management strategies should be reoriented in changing climate. Although, plant diseases play an important role in agriculture (Agrios, 2005), a limited amount of information on the potential impacts of climate change on plant diseases is available (Harvell et al., 2002 and Garrett et al., 2006).

\section{Effect of temperature on plant diseases}

Certain minimum temperature is required by both plants and pathogens to grow. Temperature affects the chain of events in disease cycles such as survival, dispersal, penetration, development and also reproduction rate for many pathogens. With increasing temperature spore germination of rust fungus Puccinia substriata increases (Tapsoba and Wilson, 1997). In southern Germany, a northward shift of Cercospora beticola, leaf spot of sugar beeet was due to increasing annual mean temperature by $0.8-1{ }^{\circ} \mathrm{C}$ (Richerzhagen et al., 2011). Altered temperatures favour over wintering of sexual propagules which increased the evolutionary potential of a population (Pfender and Vollmer (1999). Generally high moisture and temperature favours and initiate disease development, as well as germination and proliferation of fungal spores of diverse pathogens (Agrios, 2005). Conidia of powdery mildew have the ability to germinate even at $0 \%$ relative humidity (RH) (Yarwood, 1978). Conidia of Erisiphe cichoracearum germinate at temperature from 7 to $32^{\circ} \mathrm{C}$ with a $\mathrm{RH}$ of 60 to $80 \%$ (Khan and Khan, 1992); and spores of Erysiphe necator germinate at temperatures from 6 to $23^{\circ} \mathrm{C}$ with a RH from 33 to $90 \%$ (Bendek et al., 2007). 
Cereal crops become more susceptible to rust diseases because of temperature influence. Oat stem rust resistance genes $\mathrm{Pg} 3$ and $P g 4$ fail at temperature above $20^{\circ} \mathrm{C}$ (Martens et al., 1967). Likewise, wheat leaf rust resistance genes viz., $L r 2 a, L r 210$ and $L r 217$ are temperature sensitive. Only $L r 2 a$ gene shows resistance at temperature beyond $25^{\circ} \mathrm{C}$. In contrast, lignification in forage crops increases with higher temperature (Wilson et al., 1991). Moderate temperature is the best for fungal growth that cause plant disease. Phytophthora infestans, late blight of potato and tomato, infects and reproduces most successfully at high moisture when temperatures are between $7.2^{\circ} \mathrm{C}$ and $26.8^{\circ} \mathrm{C}$. Infection of Eucalyptus sp. by Phytophthora cinnamomi due to increased soil temperature of $12-30^{\circ} \mathrm{C}$ (Podger et al., 1990). Temperature also plays a vital role for the occurrence of bacterial diseases such as Ralstonia solanacearum, Acidovorax avenae and Burkholderia glumea and bacteria also proliferate in the areas where temperature dependent diseases have not been previously observed (Kudela, 2009). Even the incidence of virus and other vectorborne diseases also alter. Mild and warmer winters make aphids easy to survive thus spreading Barley yellow dwarf virus (BYDV) and also increase viruses of potato and sugar beet (Thomas, 1989; Mackerron et al., 1993).

\section{Effect of moisture on plant disease}

With increased temperature various models on climate change predict frequent and extreme rainfall events and higher atmospheric water vapour concentrations. These encourage the crops to produce healthier and larger canopies that retain moisture as leaf wetness and $\mathrm{RH}$ for longer periods and results in condition conducive for pathogens and diseases such as late blights and vegetable root diseases including powdery mildews (Coakley et al., 1999). High moisture favours foliar diseases and some soil borne pathogens such Phytophthora, Pythium, R. solani and Sclerotium rolfsii. Drought stress affect the incidence and severity of viruses such as Maize dwarf mosaic virus (MDMV) and Beet yellows virus (BYV) (Olsen et al., 1990 and Clover et al., 1999).

\section{Effect of $\mathrm{CO}_{2}$ on plant disease}

Both the host and the pathogen are influenced by increased $\mathrm{CO}_{2}$ levels in various ways. Increased size of plant organs, leaf area, leaf thickness, more numbers of leaves, higher total leaf area/plant, stems and branches with greater diameter are resulted from increased $\mathrm{CO}_{2}$ levels (Bowes, 1993 and Pritchard et al., 1999). Dense canopy favours the incidence of rust, powdery mildew, Alternaria blight, Stemphylium blight and anthacnose diseases. Higher $\mathrm{CO}_{2}$ concentrations induce greater fungal spore production. Increased $\mathrm{CO}_{2}$ also enhances photosynthesis, increased water use efficiency and reduced damage from ozone (von Tiedmann and Firsching, 2000); and leaf area, plant height and crop yield are increased at higher doses of $\mathrm{CO}_{2}$ (Eastburn et al., 2011). The physiological changes on the host plant due to increased $\mathrm{CO}_{2}$ can conversely result in increase host resistance to pathogens (Coakley et al., 1999). 
Under elevated $\mathrm{CO}_{2}$ conditions, potential of dual mechanism i.e., reduced stomata opening and altered leaf chemistry results in reduced disease incidence and severity in many plant pathosystems where the pathogen targets the stomata (Mcelrone et al., 2005). In soybean, elevated concentration of $\mathrm{CO}_{2}$ and $\mathrm{O}_{3}$ altered the expression of 3 soybean diseases, downy mildew (Perenospora manshurica), brown spots (Septoria glycines) and sudden death syndrome (Fusarium virguliforme) and response to the diseases varied considerably (Eastburn et al., 2010). Elevated $\mathrm{CO}_{2}$ also leads to production of papillae and accumulation of silicon by barley plants at the site of appressorial penetration of Erysiphe graminis and changed leaf chemistry that decrease susceptibility to the powdery mildew pathogen (Hibberd et al., 1996). In general, the effects of elevated $\mathrm{CO}_{2}$ concentration on plant diseases can be positive or negative, but majority of the cases disease severity increased (Manning and Tiedmann, 1995). Besides all that mentioned above, change in temperature and other climatic factors make the plants vulnerable to pathogens are currently not important owing to unfavourable climate. For example, drought condition favours infection by Armilaria sp. which is normally not very pathogenic (Rishbeth, 1991 and Lonsdale and Gibbs, 1996).

\section{Climate change and microbial interactions}

Increased $\mathrm{CO}_{2}$ levels in the atmosphere have major consequences on carbon cycling and the functioning of various ecosystems. Nitrogen deposition level, $\mathrm{CO}_{2}$ concentration and temperature are important factors affecting soil microbial communities (Garret et al., 2006). Short-term and long-term changes in the abiotic conditions not only affect plant growth and productivity but also the populations of microorganisms living on plant surfaces. Any change in phyllosphere microflora, affects plant growth and plants' ability to withstand aggressive attack of pathogens.

\section{Effect of climate change on vector-borne diseases}

Plant viruses operate in association with their host plants and vectors. The risk of vector-borne disease at the local and regional level is limited by the climatic requirements of disease vectors (Malmstrom et al., 2011). Both host plant and insectvector populations are affected by climate change and spread the plant viruses (Jones, 2009). Global warming also influences the primary infection of the host, the spread of the infection within the host and/or the horizontal transmission of the virus to new hosts by the vector. Phenology and physiology of the host also affected by climate change, thereby affect its virus susceptibility and virus ability to infect. In turn, effects on host physiology may affect the attractiveness of the host to vectors and/or viral transmissibility. Climate change has various effects on vectors like modification of vector phenology, vector's over-wintering, density, migration and its stability. There is a little effect by elevated $\mathrm{CO}_{2}$ levels on natural enemies of insect herbivores. This elevated $\mathrm{CO}_{2}$ have indirect effect on third trophic level, by changing the size and composition of insects prey populations. Any changes either in host plant or insect vector population due to climate change could spread plant viruses (Canto et al., 2008). 


\section{Plant pathosystems models}

To study the effects of climate change on both plant pathogens and diseases, pathosystem are examined (Elad and Pertot, 2014). Predictive models have been developed for a few plant-pathogen systems. Powdery mildew (E. necator) is one of the most important diseases of grapevine and European grapevine moth (Lobesia botrana) is one of the most noxious vineyard pests in the European and Mediterranean regions. Phenological models of grapevine with phenological models of grape powdery mildew and the European grapevine moth applied the models to climate change scenarios for the eastern Italian Alps and considered potential changes in the interactions between these species (Caffarra et al., 2012). They simulate decrease powdery mildew epidemics in disease severity, especially in years where disease symptoms first appear at a later date and in the presence of increased temperatures. They also suggested that in the warmer region with profitable viticulture areas, increased temperatures might have a detrimental effect on yield because of increased asynchrony between the growth stages of resistant larvae of grapevine and European grapevine moth larvae. On the other hand, the increase in pest pressure caused by the increased number of generations might not be as severe as expected on the basis of the pest model only, because of the earlier harvest dates, which would limit the damage caused by late-season generations. Moisture allows for infection by zoosporangia and dry periods kill the pathogen (Gessler et al., 2011).

\section{North-eastern scenario on plant disease}

This region fall under high rainfall zone with subtropical type of climate (Das et al., 2009 ) and several crop diseases occurred with varying levels of incidence (Ao et al., 2014). Cereal, spices and vegetables are affected by many diseases with changing climate. High incidence of colocasia leaf blight and with moderate incidence of blast and brown spot of paddy, bacterial blight of paddy, Curvularia leaf pot of maize, anthracnose and fruit rot of king chilli, leaf blotch and leaf spot of turmeric, powdery mildew and downy mildew of cucurbits, tomato leaf curl, sigatoka and anthracnose of banana and citrus canker diseases. Another effect that is drought and flood are adverse climatic conditions from deficit and excess rainfall and greatly hamper the agricultural crops.

In the past few years, with deficient precipitation, there is a possibility of occurring moisture stress condition which favours plant diseases like Macrophomina, Rhizoctonia, etc in pulse crops. Though there is no specific study reported from region on the impact of climate change on plant diseases, however, we can assumed and foreseen several findings with scientific considerations in the line of the studies conducted elsewhere.

\section{Coping with the effects of climate change on plant diseases}

Disease development is the cumulative effect of various factors that affect the host and pathogen. Microbial populations or control agents also affect the plant- 
pathogen relationship. The effects of climate change differ in different plantpathogen systems. Because of severe climatic conditions crops require more fungicide spray treatments with higher application rates, thus increasing costs for farmers, prices for consumers and the likelihood of the development of fungicide resistance (Juroszek and von Tiedemann, 2011). Annual crops have an advantage over perennials, as they are more flexible and when it comes to adopt new cultivars and cultural practices. To cope with the predicted climate change, one can evaluate the efficacy of current physical, chemical and biological control methods and also by adapting new tool and techniques. The persistence of plant protection chemicals in the phyllosphere is highly dependent on weather conditions. The efficacy of chemical pesticides can affect by change in duration, intensity and frequency of precipitation events. Temperature directly influences the degradation of chemicals and alters plant physiology and morphology; indirectly affecting the penetration, translocation, persistence and modes of action of many systemic fungicides (Coakley et al., 1999).

\section{CONCLUSION}

There has been only a limited research on impact of climate change on plant diseases under field conditions or disease management under climate change. However, some assessments are now available for few countries, regions, crops and particular pathogens which concern with food security. Now, emphasis must shift from impact assessment to developing adaptation and mitigation strategies and options. First, there is need to evaluate under climate change the efficacy of current physical, chemical and biological control tactics, including disease-resistant cultivars, and secondly, to include future climate scenarios in all research aimed at developing new tools and tactics. Disease risk analyses based on host-pathogen interactions should be performed, and research on host response and adaptation should be conducted to understand how an imminent change in the climate could affect plant diseases.

\section{ACKNOWLEDGEMENTS}

The authors are grateful to the Dean, College of Post Graduate studies, Central Agricultural University, Umiam, Meghalaya, India for supporting authors to conduct the study.

\section{REFERENCES}

Agrios, G. N. 2005. Plant Pathology. p. 249-263. $5^{\text {th }}$ edition. London: Elsevier

Ahanger, R. A., Bhat, H. A., Bhat, T. A., Ganie, S. A., Lone, A. A., Wani, I. A., Ganai, S. A., Haq, S., Khan, O. A., Junaid, J. M. and Bhat, T. A. 2013. Impact of Climate Change on Plant Diseases. International Journal of Modern Plant \& Animal Sciences, 1(3): 105115 
Ao, N. T., Banik, S., Daiho, L., Ao, M. A., Pongener, N. and Neog, P. 2014. Report on crop disease and pest survey in Dimapur and Peren districts of Nagaland. SASRD, Nagaland University

Bendek, C. E., Campbell, P. A., Torres, R., Donoso, A., Latorre, B. A. 2007. The risk assessment index in grape powdery mildew control decisions and the effect of temperature and humidity on conidial germination of Erysiphe necator. Spanish Journal of Agricultural Research, 5(4): 522-532

Bowes, G. 1993. Facing the inevitable: plants and increasing atmospheric $\mathrm{CO}_{2}$. Annual Review of Plant Physiology and Plant Molecular Biology, 44: 309-32

Caffarra, A., Rinaldi, M., Eccel, E., Rossi, V. and Pertot, I. 2012. Modeling the impact of climate change on the interaction between grapevine and its pests and pathogens: European grapevine moth and powdery mildew. Agriculture, Ecosystems \& Environment, 148: 89-101

Canto, T., Aranda, M. and Fereres, A. 2008. Climate change effects on physiology and population processes of host and vectors that influence the spread of hemipteran-borne plant viruses. Global Change Biology, 15(8): 1884-1894

Chakraborty, S. 2005. Potential impact of climate change on plant-pathogen interactions. Australasian Plant Pathology, 34: 443-448

Chakraborty, S. and Newton, A. C. 2011. Climate change, plant diseases and food security: an overview. Plant Pathology, 60: 2-14

Chakraborty, S., Tiedemann, A. V. and Teng, P. S. 2000. Climate change: potential impact on plant diseases. Environmental Pollution, 108: 317-326

Clover, G. R. G., Smith, H. G., Azam-Ali, S. N. and Jaggard, K. W. 1999. The effects of drought on sugar beet growth in isolation and in combination with Beet yellows virus (BYV) infection. Journal of Agricultural Science, 133: 251-261

Coakley, S. M., Scherm, H. and Chakraborty, S. 1999. Climate change and plant disease management. Annual Review of Phytopathology, 37: 399-426

Das, A., Ghosh, P. K., Choudhury, B. U., Patel, D. P., Munda, G. C., Ngachan, S. V. and Chowdhury, P. 2009. Climate change in Northeast India: Recent facts and eventsworry for agricultural management. In Proceedings: Impact of Climate Change on Agriculture. 17-18 Dec., 2009. Ahamedabad, India

Eastburn, D. M., Degennaro, M. M., Delucia, E. H., Dermody, O. and Mcelrone, A. J. 2010. Elevated atmospheric carbon dioxide and ozone alter soybean diseases at SoyFACE. Global Change Biology, 16: 320-330

Eastburn, D. M., McElrone, A. J. and Bilgin, D. D. 2011. Influence of atmospheric and climatic change on plant-pathogen interactions. The Plant Pathology, 60: 54-59.

Elad, Y. and Pertot, I. 2014. Climate change impacts on plant pathogens and plant diseases. Journal of Crop Improvement, 28(1): 99-139.

Evans, N., Baierl, A., Semenov, A. M., Gladders, P. and Fitt, B. D. L. 2007. Range and severity of a plant disease increased by global warming. Journal of The Royal Society Interface, 5: 525-531 
Garrett, K. A., Dendy, S. P., Frank, E. E., Rouse, M. N. and Travers, S. E. 2006. Climate change effects on plant disease: genomes to ecosystems. Annual Review of Phytopathology, 44: 489-509

Gautam, H. R., Bhardwaj, M. L. and Kumar, R. 2013. Climate change and its impact on plant diseases. Current Science, 105(12): 1685-1691

Gessler, C., Pertot, I. and Perazzolli, M. 2011. Plasmopara viticola: A review of knowledge on downy mildew of grapevine and effective disease management. Phytopathologia Mediterranea, 50: 3-44

Ghini, R, Hamada, E, Bettiol, W. 2008. Climate change and plant disease. Scientia Agricola (Piracicaba, Brazil), 65: 98-107

Harvell, C. D., Mitchell, C. E., Ward, J. R., Altizer, S., Dobson, A. P., Ostfeld, R. S. and Samuel, M. D. 2002. Climate warming and disease risks for terrestrial and marine biota. Science, 296: 2158-2162

Hibberd, J. M., Whitbread, R., Farrar, J. F. 1996. Effect of elevated concentrations of $\mathrm{CO}_{2}$ on infection of barley by Erysiphe graminis. Physiological and Molecular Plant Pathology, 48: 37-53

IPCC. 2007. Climate change 2007: Synthesis Report. Contribution of Working Group I, II and III to the Fourth Assessment Report of the Intergovernmental Panel on Climate Change (IPCC). R. K. Pachauri and A. Reisinger (Eds.), IPCC, Geneva, Switzerland.

Jones, R. A. C. 2009. Plant virus emergence and evolution: origins, new encounter scenarios, factors driving emergence, effects of changing world conditions, and prospects for control. Virus Research, 141: 113-130

Juroszek, P. and von Tiedemann, A. 2011. Potential strategies and future requirements for plant disease management under a changing climate. Plant Pathology, 60: 100-112

Kaczmarek, J., Kedziora, A., Brachaczek, A., Akinwunmi, O., Dada, L., Dakowska, S., Karg, G. and Jedryczka, M. 2016. Effect of climate change on sporulation of the teleomorphs of Leptosphaeria species causing stem canker of brassicas. Aerobiologia, 32: $39-51$

Khan, A. U. and Khan, A. M. 1992. Incidence and severity of cucurbit powdery mildew in Uttar Pradesh. Indian Phytopathology, 45(2): 190-193

Kobayashi, T., Ishiguro, K., Nakajima, T., Kim, H. Y., Okada, M. and Kobayashi, K. 2006. Effects of elevated atmospheric $\mathrm{CO}_{2}$ concentration on the infection of rice blast and sheath blight. Phytopathology, 96: 425-431

Kudela, V. 2009. Potential Impact of Climate Change on Geographic Distribution of Plant Pathogenic Bacteria in Central Europe. Plant Protection Science, 45: 527-532

Legreve, A. and Duveiller, E. 2010. Preventing potential diseases and pest epidemics under a changing climate. p. 50-70. In M. P. Reynolds (ed.), Climate change and crop production. Wallingford, CABI

Lonsdale, D. and Gibbs, J. N. 1996. Effects of climate change on fungal diseases of trees. p. 1019. In: Frankland et al. (Eds.), Fungi and Environmental Change. Cambridge University Press, Cambridge 
Luck, J., Spackman, M., Freeman, A., Griffiths, W., Finlay, K. and Chakraborty, S. 2011. Climate change and diseases of food crops. Plant Pathology, 60(1): 113-121

Mackerron, D., Boag, B., Duncan, J. M., Harrison, J. G. and Woodford, J. A. T. 1993. The prospect of climate change and its implications for crop pests and diseases. P. 181-93. In D. Ebbels (Eds.) Plant Health and the European Single Market. Farnham: British Crop Production Council

Mahato, A. 2014. Climate Change and its Impact on Agriculture. International Journal of Scientific and Research Publications, 4(4).www.ijsrp.org.

Malmstrom, C. M., Melcher, U. and Bosque-Perezc, N. A. 2011. The expanding field of plant virus ecology: Historical foundations, knowledge gaps, and research directions. Virus Research, 159: 84-94.

Manning, W. J. and Tiedemann, A. 1995. Climate change: potential effects of increased atmospheric carbon dioxide $\left(\mathrm{CO}_{2}\right)$, ozone $\left(\mathrm{O}_{2}\right)$ and ultraviolet-B (UV-B) radiation on plant disease. Environmental Pollution, 88: 219-246

Martens, J. W., McKenzie, R. I. H. and Green, G. J. 1967. Thermal stability of stem rust resistance in oat seedlings. Canadian Journal of Botany, 45: 451-58

Mcelrone, A. J., Reid, C. D., Hoye, K. A., Hart, E.and Jackson, R. B. 2005. Elevated $\mathrm{CO}_{2}$ reduces disease incidence and severity of a red maple fungal pathogen via changes in host physiology and leaf chemistry. Global Change Biology, 11: 1828-1836

Olsen, A. J., Pataky, J. K., D'arcy, C. J. and Ford, R. E. 1990. Effects of drought stress and infection by Maize dwarf mosaic virus (MDMV) in sweet corn. Plant Disease, 74: 147151

Pachauri, R. K., Allen, M. R., Barros, V. R., Broome, J., Cramer, W., Christ, R., Church, J. A., Clarke, L., Dahe, Q., Dasgupta, P., Dubash, N. K., Edenhofer, O., Elgizouli, I., Field, C. B., Forster, P., Friedlingstein, P., Fuglestvedt, J., Gomez-Echeverri, L., Hallegatte, S., Hegerl, G., Howden, M., Jiang, K., Jimenez Cisneroz, B., Kattsov, V., Lee, H., Mach, K. J., Marotzke, J., Mastrandrea, M. D., Meyer, L., Minx, J., Mulugetta, Y., O’Brien, K., Oppenheimer, M., Pereira, J. J., Pichs Madruga, R., Plattner, G. K., Portner, H. O., Power, S. B., Preston, B., Ravindranath, N. H., Reisinger, A., Riahi, K., Rusticucci, M., Scholes, R., Seyboth, K., Sokona, Y., Stavins, R., Stocker, T. F., Tschakert, P., van Vuuren, D. and Van Ypserle, J. P. 2014. Climate change 2014: Synthesis report. p.151. In R. Pachauri and L. Meyer (Eds.) Contribution of working groups I, II and III to the fifth assessment report of the intergovernmental panel on climate change. Switzerland. Geneva

Pfender, W. F. and Vollmer, S. S. 1999. Freezing Temperature Effect on Survival of Puccinia graminis sub sp. graminicola in Festuca arundinacea and Lolium perenne. Plant Disease, 83: 1058-1062

Podger, F. D., Mummery, D. C., Palzer, C. R. and Brown, M. L. 1990. Bioclimatic analysis of the distribution of damage to native plants in Tasmania by Phytophthora. Australian Journal of Ecology, 15: 281-289.

Pritchard, S. G., Rogers, H. H., Prior, S. A. and Peterson, C. M. 1999. Elevated $\mathrm{CO}_{2}$ and plant structure: A review. Global Change Biology, 5: 807-837 
Prospero, S., Grunwald, N. J., Winton, L. M. and Hansen, E. D. M. 2009. Migration patterns of the emerging plant pathogen Phytophthora ramorum on the west coast of the United States of America. Phytopathology, 99: 739-749

Regniere, J. 2012. Invasive species, climate change and forest health. p. 27-37. In T. Schlichter and L. Montes (Eds.) Forests in Development: A Vital Balance. Springer. Berlin.

Richerzhagen, D., Racca, P., Zeuner, T., Kuhn, C., Falke, K., Kleinhenz., B. and Hau, B. 2011. Impact of climate change on the temporal and regional occurrence of Cercospora leaf spot in Lower Saxony. Journal of Plant Diseases and Protection, 118: 168-177

Rishbeth, J. 1991. Armillaria in ancient broad leaved woodland. European Journal of Forest Pathology, 21: 239-249

Rosenzweig, C. And Tubiello, F. N. 2007. Adaptation and mitigation strategies in agriculture: an analysis of potential synergies. Mitigation and Adaptation Strategies for Global Change, 12: 855-873

Tapsoba, H. and Wilson, J. P. 1997. Effects of Temperature and Light on Germination of Urediniospores of the Pearl Millet Rust Pathogen, Puccinia substriata var. indica. Plant Disease, 81(9): 1049-1052

Thomas, T. 1989. Sugar beet in the greenhouse - a global warning. Brown Sugar, 59: 24-26

Von Tiedemann, A. and Firsching, K. H. 2000. Interactive effects of elevated ozone and carbondioxide on growth and yield of leaf rust-infected versus non-infected wheat. Environmental Pollution, 108: 357-363

Wilson, J. R., Deinum, B. and Engel, F. M. 1991. Temperature effects on anatomy and digestibility of leaf and stem of tropical and temperate forage species. Netherlands Journal of Agricultural Science, 39: 31-48

Yanez-Lopez, R., Torres-Pacheco, I., Guevara-Gonzalez, R. G., Hernandez-Zul, M. I., Quijano-Carranza, J. A. and Rico-Garcia, E. 2012. The effect of climate change on plant diseases. African Journal of Biotechnology, 11(10): 2417-2428

Yarwood, C. E. 1978. History and taxonomy of powdery mildews. p.1-37. In D. M., Spencer (Eds.), Powdery Mildews. Academic Press, London 